\title{
Stabilization of Ampicillin Analogs in Aqueous Solution. I. Assay of Ampicillin in Solutions containing Benzaldehyde by Iodine Colorimetry and the Effect of Benzaldehyde on the Stability of Ampicillin
}

\author{
Hiroshi Fujiwara, Susumu Kawashima,* and Masako Ohhashi
}

School of Pharmacy, Hokuriku University, Kanagawa-machi, Kanazawa 920-11, Japan

(Received October 8, 1981)

\begin{abstract}
The interaction of ampicillin and benzaldehyde in aqueous solution was investigated. A modified iodine colorimetry $\left(\mathrm{I}_{2}\right.$-colorimetry) was used for the assay of ampicillin in solutions containing ampicillin and benzaldehyde. Thus, total ampicill $n$ including bioactive ampicillin-like substances which are present in aqueous solution could be determined by $\mathrm{I}_{2}$-colorimetry after diluting the solution and adjusting it to $\mathrm{pH} 3.5-4.0$. The time courses of degradation of ampicillin with benzaldehyde in phosphate buffer ( $\mathrm{pH} \mathrm{8.00)}$ at $35^{\circ} \mathrm{C}$ were followed by this method, and the reaction was found to be pseudo-first-order. Further, it was found that benzaldehyde inhibited the degradation of ampicillin under these conditions.

In view of the above results and the changes in the ultraviolet spectra of the solution, it is concluded that ampicillin and benzaldehyde form a complex.
\end{abstract}

Keywords_— - degradation of ampicillin; stabilization of ampicillin with benzaldehyde; complex formation; $\mathrm{I}_{2}$-colorimetry; equilibrium state

Ampicillin is a well-known broad spectrum antibiotic, but its stability is affected by various materials. For example, the degradation of ampicillin in aqueous solution is accelerated by glucose, ${ }^{1)}$ alcohols ${ }^{2)}$ and amines. ${ }^{3)}$ However, few detailed studies have been reported on the interactions between ampicillin and aldehydes. In this paper, the interaction of ampicillin with benzaldehyde was studied. We first aimed to modify the iodometry procedure used frequently as an assay method for penicillins. Secondly, we hoped to elucidate the effect of benzaldehyde on the stability of ampicillin in aqueous solution.

\section{Experimental}

Materials - Ampicillin sodium (Sigma Chemical Company), penicillin G potassium (Wako Pure Chemical Ind. Ltd.) were of guaranteed reagent grade. Benzaldehyde and all other chemicals were of the highest commercial grade available and were used without further purification.

Reagents- $\mathrm{I}_{2}$ Solution: $\mathrm{I}_{2}, 0.04 \mathrm{M}$ in $3.2 \mathrm{M} \mathrm{KI}$, was prepared according to the micro iodometric assay by Novick.

Dilute Iodine Solution (Dil. $\mathrm{I}_{2}$ Solution): $\quad 0.04 \mathrm{M} \mathrm{I}_{2}$ was diluted exactly 100 times and stored in the dark. Solutions of $1 \mathrm{~N} \mathrm{HCl}$ and $1 \mathrm{~N} \mathrm{NaOH}$ used were of analytical grade.

Buffer Solutions- - $0.05 \mathrm{M}$ Phthalate $(\mathrm{pH} 4.00): 10.22 \mathrm{~g}$ of potassium hydrogen phthalate was dissolved in water to make $1000 \mathrm{ml}$.

$0.1 \mathrm{~m}$ Phthalate: The $\mathrm{pH}$ of $0.1 \mathrm{~m}$ potassium hydrogen phthalate was adjusted to $\mathrm{pH} 4.00$ by the addition of $1 \mathrm{~N} \mathrm{HCl}$ at $35^{\circ} \mathrm{C}$.

$0.1 \mathrm{M}$ Phosphate: $\quad 0.1 \mathrm{M} \mathrm{NaH} \mathrm{PO}_{4}$ and $\mathrm{Na}_{2} \mathrm{HPO}_{4}$ were mixed well at $35^{\circ} \mathrm{C}$, to give a $\mathrm{pH}$ cf 8.00 . The ionic strength of each buffer was adjusted to 0.5 by the addition of $\mathrm{KCl}$.

Apparatus- - The $\mathrm{pH}$ values of solutions were measured using a Toa $\mathrm{pH}$ meter, model HM-18ET. The measurements of ultraviolet (UV) absorption spectra were carried out with Hitachi, model 340 machine.

Assay Method- - From a solution containing $2.5 \times 10^{-4} \mathrm{M}$ ampicillin, two equal samples of $1 \mathrm{ml}$ were pipeted into separate $25 \mathrm{ml}$ graduated test tubes with glass stoppers and adjusted to $\mathrm{pH} 3.5-4.0 \mathrm{with} \mathrm{HCl}$. The solutions were left to stand for $5 \mathrm{~min}$, then $2 \mathrm{ml}$ of $1 \mathrm{~N} \mathrm{NaOH}$ was added to one of the tubes. After 20 min at room temperature, $2 \mathrm{ml}$ of $1 \mathrm{~N} \mathrm{HCI}, 5 \mathrm{ml}$ of dil. $\mathrm{I}_{2}$ solution and phthalate buffer $(0.05 \mathrm{M})$ were added to make $25 \mathrm{ml}$. The test tube was stoppered and kept for $20 \mathrm{~min}$ in darkness at room temperature. The absorbance of the solution was measured at $350 \mathrm{~nm}$. 
To the other tube, $2 \mathrm{ml}$ of $1 \mathrm{~N} \mathrm{NaOH}$ and $1 \mathrm{~N} \mathrm{HCl}, 5 \mathrm{ml}$ of dil. $\mathrm{I}_{2}$ solution and phthalate buffer $(0.05 \mathrm{M})$ were added to make $25 \mathrm{ml}$. The solution was treated similarly and the absorbance was measured at $350 \mathrm{~nm}$. The difference between the two absorbances $(\Delta A)$ represents the amount of iodine equivalent to the ampicillin present. When the concentration of ampicillin was higher than $2.5 \times 10^{-4} \mathrm{M}$, this method caused decoloration resulting from the complete consumption of iodine by penicilloic acid. Then, the analysis was carried out by degradation with alkali followed by quantitative addition of dil. $\mathrm{I}_{2}$ solution for color development of the solution.

Bioassay-Antibacterial activity was assayed by the cylinder plate method with Staphylococcus auveus $209 P$ as a test organism and with crystalline ampicillin as the assay standard, using Brain Heart Infusion (Difco) agar.

Kinetic Procedures-Ampicillin, benzylpenicillin solution $\left(2.5 \times 10^{-4}-2.5 \times 10^{-3} \mathrm{M}\right)$ buffered to $\mathrm{pH}$ 4.00 or 8.00 with and without benzaldehyde $\left(2.5 \times 10^{-3}-2.5 \times 10^{-2} \mathrm{M}\right)$ were stored in a constant temperature bath which was regulated by a thermostat with $\pm 0.1^{\circ} \mathrm{C}$ precision. At suitable time intervals, samples were withdrawn, cooled on ice and assayed immediately. The $\mathrm{pH}$ of the solution was determined at the experimental temperature initially and at the end of the experiment. No significant change in pH was observed.

\section{Results and Discussion}

\section{Application of $I_{2}$ Colorimetry to the Determination of Ampicillin}

Novick et al. ${ }^{4}$ ) have presented a micro iodometric assay for the hydrolysis of penicillin by penicillinase. The concentration of penicillin was estimated by measuring the absorbance of the starch iodine complex at $620 \mathrm{~nm}$. In a similar study, Cole ${ }^{5)}$ determined penicillin by using the absorbance of iodine at $228 \mathrm{~nm}$. In the former case, the color development depended on conditions such as the type and concentration of starch, the technique of preparing starch solution and the $\mathrm{pH}$ of the solution. Further, the method did not give reproducible analytical data under given conditions. Thus, we improved the latter method to obtain a simple method by which penicillins could be determined directly from the absorbance of iodine used to titrate penicilloic acid. Since ampicillin and other chemicals did not decolorize iodine, the concentration of iodine could be calculated from the absorbance at $350 \mathrm{~nm}$.

The absorbance of $c a .10^{-5} \mathrm{M}$ iodine at $350 \mathrm{~nm}$ was constant below $\mathrm{pH} 4.00$ and no changes were observed during storage in darkness for $40 \mathrm{~min}$. A linear relationship between the concentration of iodine below $5 \times 10^{-5} \mathrm{M}$ and the absorbance at $350 \mathrm{~nm}$ was observed at $\mathrm{pH}<4.00$. Various concentrations of ampicillin were treated by the procedure described in "Experimental," and the extent of iodine consumption (converted into absorbance, $\Delta A$ ) was plotted against the concentration of ampicillin. A linear relationship was found as shown in Fig. 1.

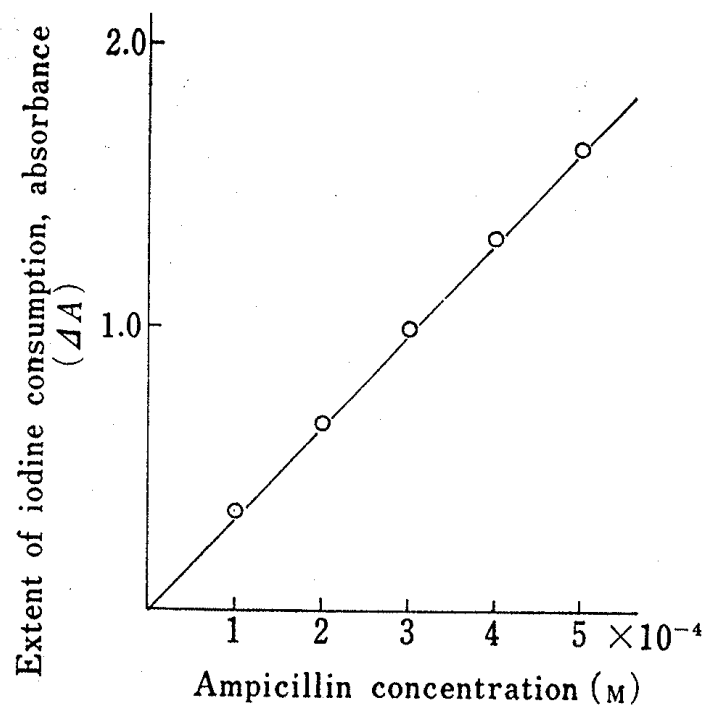

Fig. 1. Typical Calibration Curve for Ampicillin

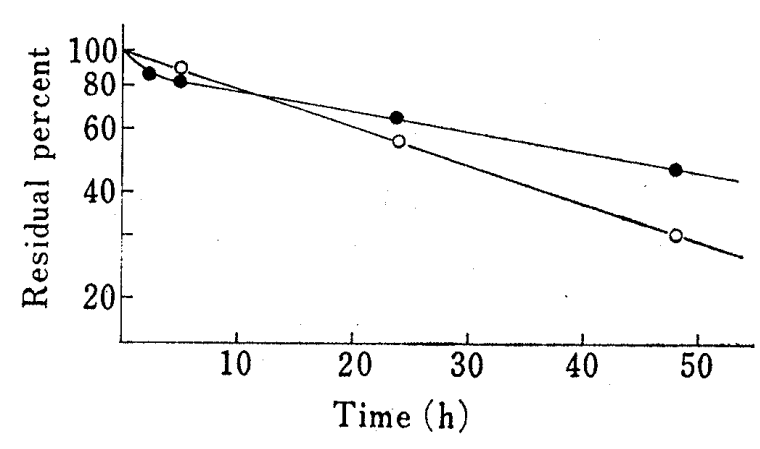

Fig. 2. Time Courses followed by $\mathrm{I}_{2^{-}}$ Colorimetry of the Degradation of Ampicillin with and without Benzaldehyde in $0.1 \mathrm{M}$ Phosphate Buffer of $\mathrm{pH} 8.00$ at $35^{\circ} \mathrm{C}$ and $\mu=0.5$

$\bigcirc$, ampicillin $2.5 \times 10^{-3} \mathrm{M} ; 0$, ampicillin $2.5 \times$ $10^{-3} \mathrm{M}$ with benzaldehyde $2.5 \times 10^{-2} \mathrm{M}$. 
Similar results were obtained with benzylpenicillin. Further, benzaldehyde below $2.5 \times$ $10^{-2} \mathrm{M}$ did not consume iodine at all in this $\mathrm{I}_{2}$-colorimetry. Therefore, from the results shown in Table I also, it was clear that ampicillin and benzylpenicillin could be successfully determined by this $\mathrm{I}_{2}$-colorimetry.

\section{$I_{2}$-Colorimetry of the Degradation Process of Ampicillin with Benzaldehyde in Aqueous Solution}

The time courses of the degradation of ampicillin was followed in phosphate buffer $(\mathrm{pH}$ 8.00 ) containing $2.5 \times 10^{-3} \mathrm{M}$ ampicillin with or without $2.5 \times 10^{-2} \mathrm{M}$ benzaldehyde at $35^{\circ} \mathrm{C}$. The results in a solution containing only ampicillin followed pseudo-first-order kinetics as shown in Fig. 2.

In a solution with benzaldehyde, however, similar plots did not show a pseudo-first-order reaction and the initial quantitative values were lower than for ampicillin alone. In this run, as the concentration of ampicillin was higher than $2.5 \times 10^{-4} \mathrm{M}$, ampicillin was determined directly by $\mathrm{I}_{2}$-colorimetry (using $\mathrm{I}_{2}$ solution diluted 10 times) without dilution. On the other hand, the time courses for benzylpenicillin of the same concentration in the buffers of pH 8.00 and 4.00 both followed pseudo-first-order kinetics, as shown in Fig. 3. In addition, no difference between the degradation rates with and without benzaldehyde was found at either $\mathrm{pH}$.

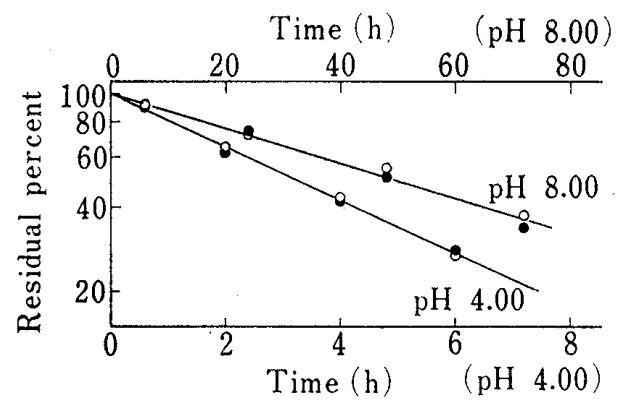

Fig. 3. Pseudo First Order Plots for the Degradation of Benzylpenicillin with and without Benzaldehyde in Buffers of $\mathrm{pH} 4.00$ and 8.00 at $35^{\circ} \mathrm{C}$ and $\mu=$ 0.5

, benzylpenicill $\mathrm{n} 2.5 \times 10^{-3} \mathrm{M}$; cillin $2.5 \times 10^{-3} \mathrm{M}$ with benzaldehyde $2.5 \times 10^{-2} \mathrm{M}$.

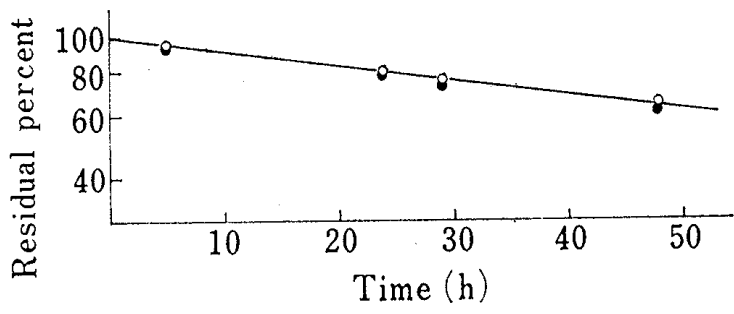

Fig. 4. Pseudo First Order Plots for the Degradation of Ampicillin with and without Benzaldehyde in $0.1 \mathrm{~m}$ Phthalate Buffer of $\mathrm{pH} 4.00$ at $35^{\circ} \mathrm{C}$ and $\mu=0.5$

, ampicillin $2.5 \times 10^{-3} \mathrm{M} ;$, ampicillin $2.5 \times 10^{-3} \mathrm{M}$ with benzaldehyde $2.5 \times 10^{-2} \mathrm{M}$.

Figure 4 shows the time courses of the degradation of ampicillin in phthalate buffer $(0.1 \mathrm{M})$ of $\mathrm{pH} 4.00$. At this $\mathrm{pH}$, the degradation of ampicillin followed apparent first-order kinetics regardless of the addition of benzaldehyde, and there was no difference in the degradation rates. That is, the application of $\mathrm{I}_{2}$ - colorimetry for the study of the degradation of benzylpenicillin in aqueous solution did not show abnormal phenomena in the presence of benzaldehyde, while that of ampicillin in phosphate buffer of $\mathrm{pH} 8.00$ showed abnormality upon the addition of benzaldehyde. Thus, there appears to be some interaction between ampicillin and benzaldehyde in the buffer of $\mathrm{pH} 8.00$.

Figure 5 shows the time courses of the degradation of ampicillin in the buffer of $\mathrm{pH} 8.00$ at $0^{\circ} \mathrm{C}$ with and without benzaldehyde. The concentrations of ampicillin without benzaldehyde were essentially constant from 98 to $101 \%$, while those with benzaldehyde gradually decreased. However, antibacterial activity of ampicillin with benzaldehyde as determined by bioassay was little changed in the solution over $120 \mathrm{~h}$ as shown in Table I. Thus, these results indicate that ampicillin and benzaldehyde formed a bioactive complex in the buffer of $\mathrm{pH} 8.00$ which could not be determined successfully by $\mathrm{I}_{2}$-colorimetry. Similar results were also obtained with hetacillin. A simultaneous determination of hetacillin and ampicillin 


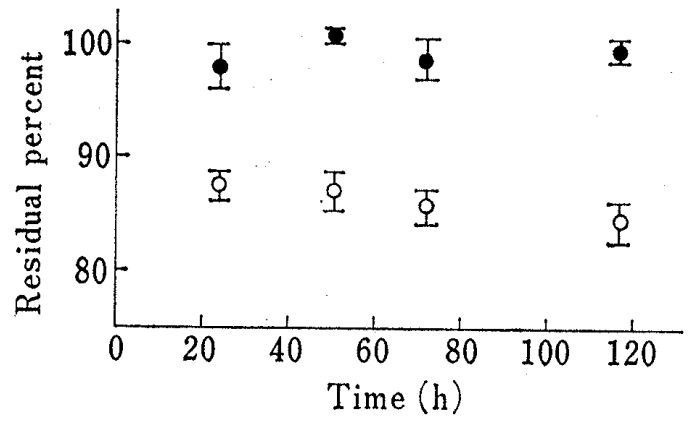

Fig. 5. Time Courses followed by $\mathrm{I}_{2}$ Colorimetry of the Degradation of Ampicillin with and without Benzaldehyde in $0.1 \mathrm{~m}$ Phosphate Buffer of $\mathrm{pH} 8.00$ at $0^{\circ} \mathrm{C}$ and $\mu=0.5$

, ampicillin $2.5 \times 10^{-3} \mathrm{M} ; \bigcirc$, ampicillin $2.5 \times$ $10^{-3} \mathrm{M}$ with benzaldehyde $2.5 \times 10^{-2} \mathrm{M}$.

The points represent the median and vertical

bars represent the standard deviations.
TABLE I. Determination of Ampicillin by $\mathrm{I}_{2}$-Colorimetry and Bioassay

\begin{tabular}{|c|c|c|c|c|}
\hline & \multicolumn{2}{|c|}{$\begin{array}{c}\mathrm{I}_{2} \text {-colorimetry } \\
(\mathrm{m} \mathrm{M})\end{array}$} & \multicolumn{2}{|c|}{$\begin{array}{l}\text { Bioassay } \\
(\mathrm{mm})\end{array}$} \\
\hline & $24 \mathrm{~h}$ & $120 \mathrm{~h}$ & $24 \mathrm{~h}$ & $120 \mathrm{~h}$ \\
\hline Ampicillin alone & 2.4 & 2.6 & 2.5 & 2.3 \\
\hline $\begin{array}{l}\text { Ampicillin with } \\
\text { benzaldehyde }\end{array}$ & 2.2 & 2.0 & 2.6 & 2.8 \\
\hline
\end{tabular}

Samples used for the analysis were $0.1 \mathrm{M}$ phosphate buffer solutions of $\mathrm{pH} 8.00$ containing $2.5 \times 10^{-3} \mathrm{M}$ ampicillin with and without $2.5 \times$ $10^{-2} \mathrm{M}$ benzaldehyde at $0^{\circ} \mathrm{C}$.

was reported by the use of iodometry and by application of the resistance of hetacillin to alkaline hydrolysis. ${ }^{6)}$

The degradation time with alkali to penicilloic acid was extended in the buffer of $\mathrm{pH} 8.00$ solution in which ampicillin had been allowed to react with benzaldehyde during 5 days at $0^{\circ} \mathrm{C}$. The results (Table II) showed that the extent of iodine consumption increased gradually with time up to $80 \mathrm{~min}$. Hence, total ampicillin containing the complex could not be determined by increasing the hydrolysis time.

On the other hand, the extent of iodine consumption increased with increase in alkali concentration upon analysis of the same solution. However, the data varied widely. Thus, it seemed that the abnormality observed in the degradation of ampicillin with benzaldehyde at $\mathrm{pH} 8.00$, as shown in Fig. 2, occurred because the complex resulting from the reaction between ampicillin and benzaldehyde was not hydrolyzed to penicilloic acids which consume iodine quantitatively on $\mathrm{I}_{2}$ - colorimetry.

Furthermore, since no abnormality of ampicillin at $\mathrm{pH} 4.00$ or of benzylpenicillin at both $\mathrm{pHs}$ was observed, it is likely that the free $\alpha$-amino group of ampicillin is involved in the formation of the complex.

TABLE II. $I_{2}$ Consumption in Terms of Absorbance for a Solution containing Ampicillin and Benzaldehyde followed by Direct $\mathrm{I}_{2}$-Colorimetry

\begin{tabular}{cccc}
\hline \multirow{2}{*}{$\begin{array}{c}\text { Time of hydrolysis } \\
(\mathrm{min})\end{array}$} & \multicolumn{3}{c}{$\begin{array}{c}\text { Absorbance, } \Delta A \\
\text { NaOH conc. }\end{array}$} \\
\cline { 2 - 4 } & $1 \mathrm{~N}$ & $3 \mathrm{~N}$ & $5 \mathrm{~N}$ \\
\hline 20 & 0.760 & 0.771 & 0.765 \\
40 & 0.782 & 0.799 & 0.831 \\
$60^{a)}$ & $0.811 \pm 0.001$ & $0.801 \pm 0.022$ & $0.874 \pm 0.111$ \\
$80^{a)}$ & $0.843 \pm 0.002$ & $0.876 \pm 0.018$ & $0.922 \pm 0.102$ \\
\hline
\end{tabular}

a) The results are means of 10 measurements.

Samples used for the analysis were $0.1 \mathrm{M}$ phosphate buffer solutions in which $2.5 \times 10^{-3} \mathrm{M}$ ampicillin had been allowed made to react with $2.5 \times 10^{-2} \mathrm{M}$ benzaldehyde at $0^{\circ} \mathrm{C}$ for $5 \mathrm{~d}$.

After storage of the buffer solution of $\mathrm{pH} 8.00$ containing $2.5 \times 10^{-3} \mathrm{M}$ ampicillin and benzaldehyde for $7 \mathrm{~d}$ at $0^{\circ} \mathrm{C}$, the time courses of degradation in the solution diluted 10 times with the buffer of $\mathrm{pH} 8.00$ or $\mathrm{pH} 4.00$ were studied on storage at $0^{\circ} \mathrm{C}$. A sample diluted with the buffer 
of $\mathrm{pH} 4.00$ gave, immediately after dilution, the same value as ampicillin itself. However, a sample diluted with the buffer of $\mathrm{pH} 8.00$ gave a lower initial value than ampicillin itself but gave the same value as ampicillin after $2 \mathrm{~h}$. It is thought that the complex dissociates into free ampicillin on dilution and that the dissociation is fast at $\mathrm{pH} 4.00$. This suggests that the total ampicillin containing the complex can be determined by dilution. The results shown in Fig. 6 were obtained by examining the time courses in buffer of $\mathrm{pH} 8.00$ in which $2.5 \times 10^{-4} \mathrm{M}$ ampicillin was allowed to react with $2.5 \times 10^{-3}$ and $2.5 \times 10^{-2} \mathrm{M}$ benzaldehyde at $35^{\circ} \mathrm{C}$. It was found that the formation of the complex increased with increase of benzaldehyde concentration and then the alkaline hydrolysis of the complex formed at $2.5 \times 10^{-4} \mathrm{M}$ ampicillin was insufficient for successful $\mathrm{I}_{2^{-}}$colorimetry. Further, it was proved that such conditions as decreasing the concentration of ampicillin to $2.5 \times 10^{-4} \mathrm{M}$, or adjusting the $\mathrm{pH}$ of the solution to $3.5-4.0$, were required for determining total ampicillin including bioactive complex in a solution of ampicillin with benzaldehyde.

The time course of the degradation of ampicillin with $2.5 \times 10^{-2} \mathrm{M}$ benzaldehyde was followed by $\mathrm{I}_{2}$-colorimetry after adjusting the $\mathrm{pH}$ of the solution to $3.5-4.0$. The plots of the logarithm of residual ampicillin versus time gave straight lines as shown in Fig. 6.

\section{Degradation of Ampicillin with Benzaldehyde in Solution}

The time courses of total ampicillin were examined by $\mathrm{I}_{2}$-colorimetry in buffer solutio of pH 8.00 containing $2.5 \times 10^{-4} \mathrm{M}$ ampicillin and $2.5 \times 10^{-3}, 1.0 \times 10^{-2}$ and $2.0 \times 10^{-2} \mathrm{M}$ benza

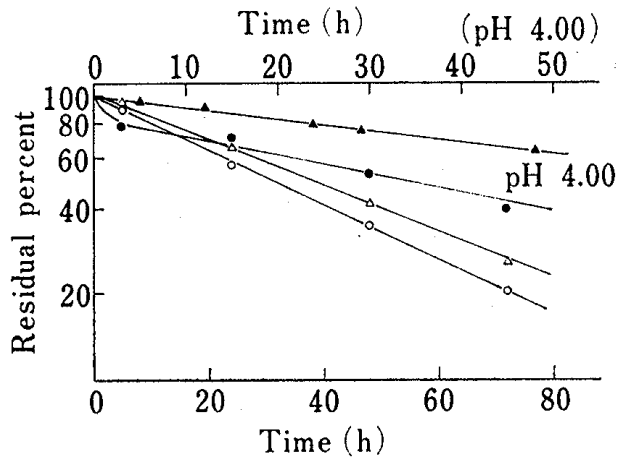

Fig. 6. Time Courses followed by $\mathrm{I}_{2}$-Colorimetry of the Degradation of Ampicillin with and without Various Concentrations of Benzaldehyde in $0.1 \mathrm{~m}$ Phosphate Buffer of $\mathrm{pH} 8.00$ and/or $0.1 \mathrm{M}$ Phthalate Buffer of $\mathrm{pH} 4.00$ at $35^{\circ} \mathrm{C}$ and $\mu=0.5$

$\bigcirc$, ampicillin $2.5 \times 10^{-4} \mathrm{M} ; \triangle$, ampicillin $2.5 \times 10^{-4} \mathrm{M}$ with benzaldehyde $2.5 \times 10^{-3} \mathrm{M} ; O, \Delta$, ampicillin $2.5 \times 10^{-4} \mathrm{M}$ with benzaldehyde $2.5 \times 10^{-2} \mathrm{M}$.

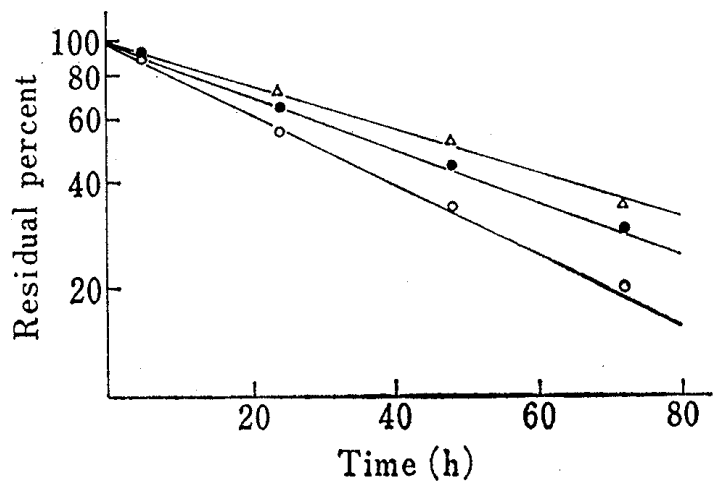

Fig. 7. Pseudo-First-Order Plots for the Degradation of Ampicillin with and without Benzaldehyde in $0.1 \mathrm{~m}$ Phosphate Buffer of $\mathrm{pH} 8.00$ at $35^{\circ} \mathrm{C}$ and $\mu=0.5$

$\bigcirc$, ampicillin $2.5 \times 10^{-4} \mathrm{M} ; 0$, ampicillin $2.5 \times 10^{-4} \mathrm{M}$ with benzaldehyde $1.0 \times 10^{-2} \mathrm{M} ; \triangle$, ampicillin $2.5 \times$ $10^{-4} \mathrm{M}$ with benzaldehyde $2.5 \times 10^{-2} \mathrm{M}$.

TABLE III. Pseudo-First-Order Rate Constants for the Degradation of Benzylpenicillin and Ampicillin with and without Benzaldehyde at Various $\mathrm{pH}$ Values, $35^{\circ} \mathrm{C}$ and $\mu=0.5$

\begin{tabular}{cccc}
\hline Penicillin & Benzaldehyde added & \multicolumn{2}{c}{ Rate constants $^{a)}\left(\mathrm{h}^{-1}\right)$} \\
& & $\mathrm{pH} \stackrel{\mathrm{pH} 8.00}{4.00}$ & $\mathrm{pH}$ \\
\hline Benzylpenicillin & 0 & 0.21 & $1.39 \times 10^{-2}$ \\
$\left(2.5 \times 10^{-4} \mathrm{M}\right)$ & $2.5 \times 10^{-3} \mathrm{M}$ & 0.20 & $1.39 \times 10^{-2}$ \\
Ampicillin & 0 & $9.15 \times 10^{-3}$ & $2.68 \times 10^{-2}$ \\
$\left(2.5 \times 10^{-4} \mathrm{M}\right)$ & $2.5 \times 10^{-3} \mathrm{M}$ & $9.92 \times 10^{-3}$ & $2.41 \times 10^{-2}$ \\
& $1.0 \times 10^{-2} \mathrm{M}$ & - & $1.97 \times 10^{-2}$ \\
& $2.5 \times 10^{-2} \mathrm{M}$ & - & $1.59 \times 10^{-2}$ \\
\hline
\end{tabular}

a) The rate constants were calculated from the analytical results obtained by $I_{2}$-colorimetry. 
dehyde at $35^{\circ} \mathrm{C}$. As shown in Fig. 7, all the plots of the logarithm of residual ampicillin versus time showed a pseudo-first-order reaction and apparent stabilization compared to a solution of ampicillin alone. Further, increasing the concentration of benzaldehyde tended to increase the stabilization. Table III summarizes the pseudo-first-order rate constants under various conditions.

As can be seen from Table III, benzaldehyde inhibits the degradation of ampicillin by the formation of a complex in the buffer of $\mathrm{pH} 8.00$. In addition, since the degradation of ampicillin with excess benzaldehyde in aqueous solution follows pseudo-first-order kinetics, it seems that the complex comes to equilibrium with ampicillin and the reversible equilibrium reaction rate is faster than the rate of degradation of ampicillin itself.

\section{UV Spectra of Ampicillin with Benzaldehyde in Solution}

To confirm that the complex which could be determined by $\mathrm{I}_{2}$-colorimetry was formed between ampicillin and benzaldehyde in the buffer of $\mathrm{pH}$ 8.00, UV spectra of the solution were examined. The buffer solution of $\mathrm{pH} 8.00$ and solution of $\mathrm{pH} 4.00$ (adjusted with $\mathrm{HCl}$ ) containing $1.0 \times 10^{-2} \mathrm{M}$ ampicillin and benzaldehyde were kept at $0^{\circ} \mathrm{C}$ and the changes of $\mathrm{UV}$ spectra of each solution were followed during aging (Fig. 8). UV spectra were measured immediately after diluting the solution 100 times with the buffers of each pH. As shown in Fig. 8 , in the buffer of $\mathrm{pH} 8.00$, the absorbance at $210 \mathrm{~nm}^{7)}$ increased, while the peak at $247 \mathrm{~nm}^{8)}$ shifted to $250 \mathrm{~nm}$ with decreasing absorbance, after $24 \mathrm{~h}$. No changes of UV spectra were found in the subsequent measurements. Further, it seemed that the UV spectrum observed after $24 \mathrm{~h}$. was that of the complex.

On the other hand, the absence of changes of absorption spectra at $\mathrm{pH} 4.00$ after $24 \mathrm{~h}$ indicated noncomplexation. Thus, these results were consistent with the kinetic data shown in Fig. 4. Furthermore, the initial absorption curve at each $\mathrm{pH}$ was in fair agreement with the sum of those of ampicillin and benzaldehyde. The buffer solution of $\mathrm{pH} 8.00$ described

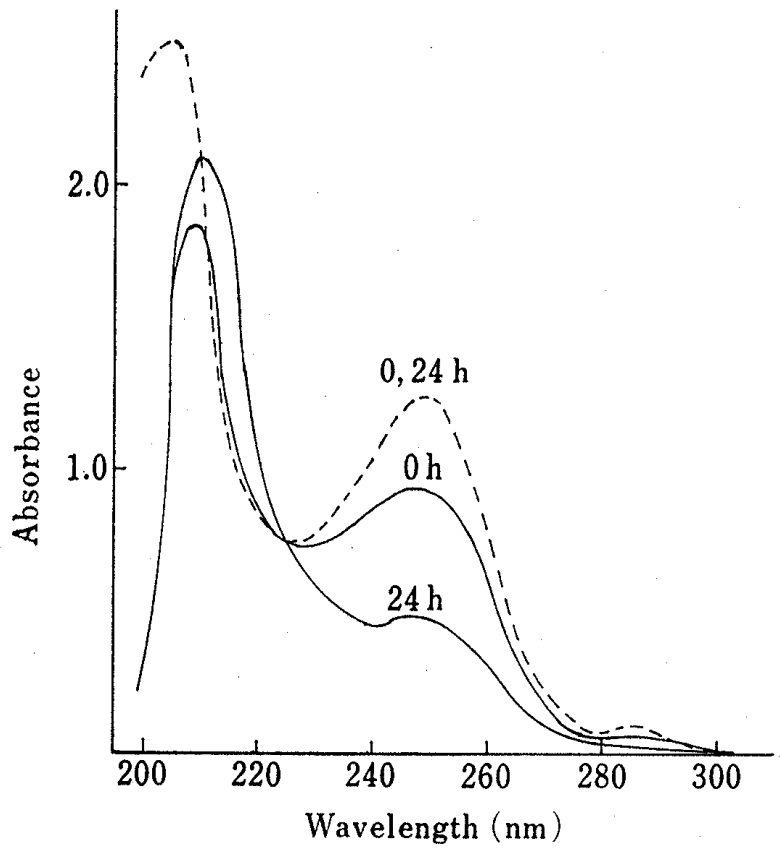

Fig. 8. Spectral Changes of a Solution containing $1.0 \times 10^{-2} \mathrm{M}$ Ampicillin and Benzaldehyde at $\mathrm{pH} 8.00$ or 4.00 , at $0^{\circ} \mathrm{C}$

$\longrightarrow$, at $\mathrm{pH} 8.00 ;-\cdots$, at $\mathrm{pH} 4.00$.

Figures on the plot are time after mixing (in hour).

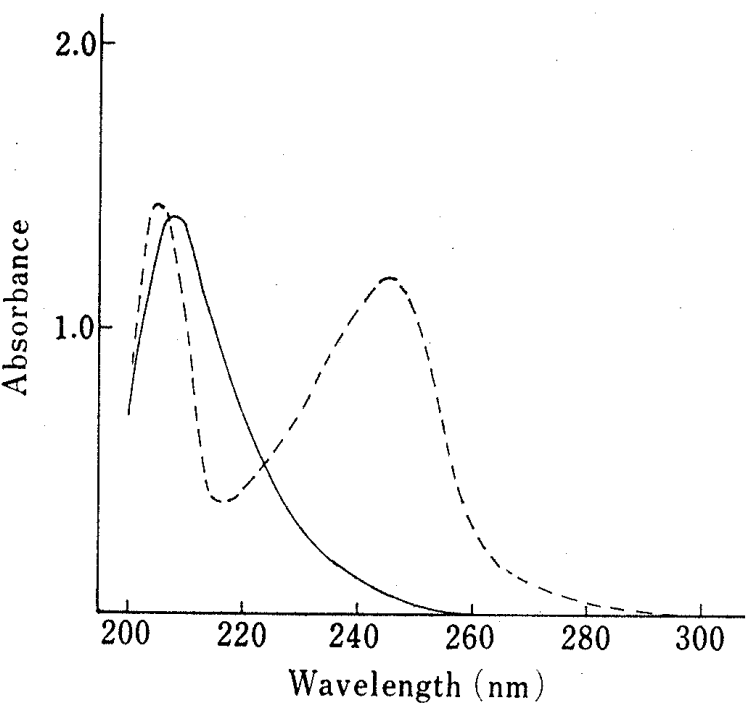

Fig. 9. UV Spectra of Ampicillin and Benzaldehyde at $\mathrm{pH} 4.00$

\footnotetext{
- ampicillin; --.--, benzaldehyde.

The concentrations of ampicillin and benzaldehyde were $1.0 \times 10^{-2} \mathrm{M}$ each.
} 
above, after standing for $72 \mathrm{~h}$ at $0^{\circ} \mathrm{C}$, was diluted 100 times with the buffer of $\mathrm{pH} 8.00$ or hydrochloric acid solution of $\mathrm{pH} 4.00$ and then the changes of UV spectra were measured.

As shown in Fig. 10, the absorbance at $210 \mathrm{~nm}$ decreased, while the peak at $250 \mathrm{~nm}$ shifted to $247 \mathrm{~nm}$ with increasing absorbance in a dilute solution of $\mathrm{pH} 8.00$.

No changes of the absorption spectra, which possessed isosbestic points at 225 and $275 \mathrm{~nm}$, were observed after $180 \mathrm{~min}$. In hydrochloric acid solution of $\mathrm{pH} 4.00$, similar changes of UV spectra were observed, and stopped after $3 \mathrm{~min}$. Further, the latter absorption curve was consistent with sum of the individual ones, as shown in Fig. 8 . These results indicate that the complex dissociates into ampicillin and benzaldehyde on dilution and that the dissociation rate at $\mathrm{pH} 4.00$ is fast compared to that at $\mathrm{pH} 8.00$.
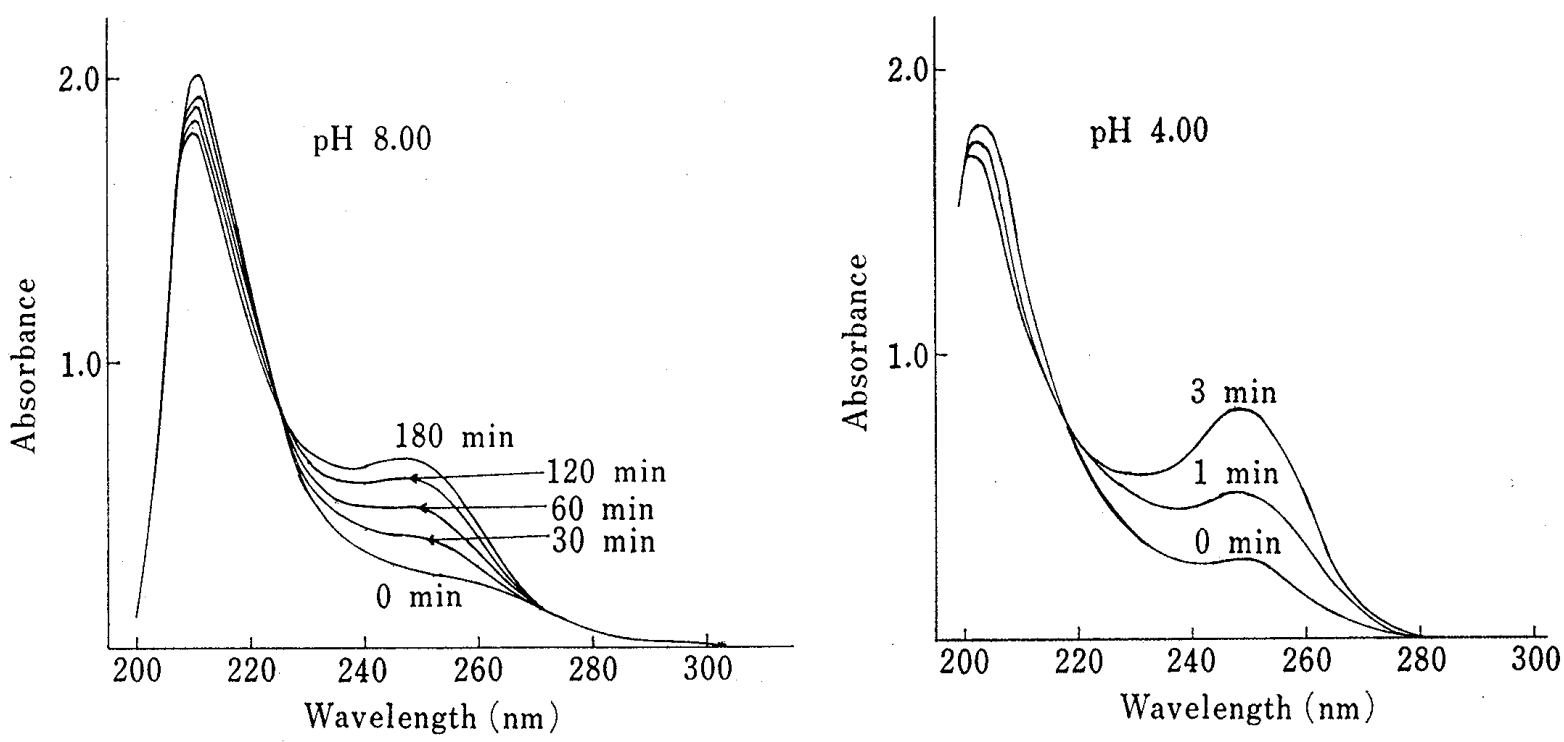

Fig. 10. Spectral Changes of a Solution of $1.0 \times 10^{-2} \mathrm{M}$ Ampicillin with $1.0 \times 10^{-2} \mathrm{M}$ Benzaldehyde after Dilution with the Buffer of $\mathrm{pH} 8.00$ or 4.00 at $0^{\circ} \mathrm{C}$

Figures on the plot are time after mixing (in min).

Thus, it was demonstrated that total ampicillin containing the complex could be determined completely by adjusting the $\mathrm{pH}$ of the solution to 4.0 for $\mathrm{I}_{2}$-colorimetry.

Acknowledgement Presented in part at the 100th annual meeting of the Pharmaceutical Society of Japan, Tokyo, April 1980. The authors thank Professor K. Yabu of this University for Bioassay and Misses T. Kitajima and Y. Hama for technical assistance.

\section{References}

1) H. Bundgaad and C. Larsen., Int. J. Pharm., 1, 95 (1978).

2) C.H. Schneider and A.L. DE Weck., Immunochemistry, 4, 331 (1967).

3) N.P. Gensmantel and M.I. Dage., J. Chem. Soc. Perkin Trans. 2, 1979, 137; A. Tsuji and T. Yamana., J. Pharm. Pharmacol., 27, 580 (1975).

4) R.P. Novick, Biochem. J., 83, 236 (1962).

5) M. Cole, S. Elson, and P.D. Fullbrook, Biochem. J., 127, 295 (1972).

6) A. Tsuji and T. Yamana, Chem. Pharm. Bull., 22, 2434 (1974).

7) J.P. Hou and J.W. Pool, J. Pharm. Sci., 58, 447 (1969).

8) A.E. Gillam, E.S. Stern, and E.R.H. Jones, "An Introduction to Electronic Absorption Spectroscopy in Organic Chemistry," 2nd ed., Edward Arnold Ltd., London, 1957. 